\title{
ANALISIS PERBANDINGAN KINERJA NON-KEUANGAN MENGGUNAKAN PERSPEKTIF PELANGGAN DARI BALANCED SCORECARD
}

\author{
Linda Mauliani Purnamasari
}

\begin{abstract}
ABSTRAK
PT. Bank Negara Indonesia (Persero) Tbk adalah salah satu lembaga keuangan yang telah menerapkan Balanced Scorecard dalam pengukuran kinerjanya sejak tahun 2006. Dalam penelitian ini yang dijadikan objek penelitian adalah BNI Kantor Layanan UPI Bandung dan BNI Kantor Layanan Ganesha dibawah Kantor Cabang Perguruan Tinggi Bandung. Menurut data yang diperoleh BNI KLN UPI dan BNI KLN Ganesha belum secara maksimal dalam hal kinerja pelayanan. Berdasarkan permasalahan tersebut, maka diadakan penelitian mengenai analisis perbandingan kinerja non-keuangan menggunakan perspektif pelanggan dari Balanced Scorecard. Tujuan dari penelitian ini adalah untuk mengetahui gambaran kinerja non-keuangan menggunakan perspektif pelanggan dari Balanced Scorecard pada BNI Kantor Layanan UPI Bandung dan BNI Kantor Layanan Ganesha Bandung, serta untuk mengetahui apakah terdapat perbedaan mengenai kinerja non-keuangan menggunakan perspektif pelanggan dari Balanced Scorecard pada BNI Kantor Layanan UPI Bandung dan BNI Kantor Layanan Ganesha Bandung. Metode penelitian yang digunakan adalah metode kuantitatif guna untuk memperoleh gambaran atau deskripsi mengenai kinerja non-keuangan menggunakan perspektif pelanggan dari Balanced Scorecard pada BNI Kantor Layanan UPI Bandung dan BNI Kantor Layanan Ganesha Bandung. Hasil penelitian ini menunjukkan bahwa BNI Kantor Layanan UPI Bandung mencapai kepuasan nasabah sebesar 79,05\% sedangkan BNI Kantor Layanan Ganesha Bandung mencapai kepuasan nasabah $75,48 \%$, sehingga dapat disimpulkan bahwa BNI Kantor Layanan UPI Bandung dan BNI Kantor Layanan Ganesha Bandung tidak mencapai target yang ditentukan yaitu sebesar $95 \%$. Dan hasil analisis perbandingan menggunakan $t$-test sample independent menunjukkan tidak ada perbedaan antara kepuasan pelanggan yang dicapai BNI Kantor Layanan UPI Bandung dan BNI Kantor Layanan Ganesha Bandung. Dari hasil penelitian tersebut maka perusahaan diharapkan dapat meningkatkan kinerjanya guna meningkatkan kepuasan pelanggan.
\end{abstract}

Kata Kunci : Kinerja Non-Keuangan, Perspektif Pelanggan, Balanced Scorecard

\section{Pendahuluan}

Munculnya era pasar bebas membawa dampak persaingan bisnis yang semakin ketat. Kondisi ini memacu dunia usaha untuk lebih peduli terhadap strategi yang dijalankan. Bahkan perusahaanperusahaan terus berupaya merumuskan dan menyempurnakan strategi-strategi bisnis mereka dalam rangka memenangkan persaingan.

Persaingan domestik dan global
mengharuskan perusahaan menaruh

perhatian pada penciptaan dan pemeliharaan keunggulan bersaing melalui penyampaian produk dan layanan yang lebih baik pada konsumen. Untuk dapat menjamin suatu organisasi berlangsung dengan baik, maka organisasi perlu mengadakan evaluasi terhadap kinerjanya. Dalam evaluasi tersebut diperlukan suatu standar pengukuran kinerja yang tepat, dalam arti tidak hanya berorientasi pada sektor keuangan saja, karena hal tersebut sangat kurang tepat dalam menghadapi persaingan bisnis yang semakin ketat. Oleh 
karena itu perlu dilengkapi dengan informasi dari sektor non keuangan, seperti kepuasan konsumen, kualitas produk atau jasa, loyalitas karyawan dan sebagainya, sehingga pihak manajemen perusahaan dapat mengambil keputusan yang tepat untuk kepentingan hidup perusahaan dalam jangka panjang.

Umumnya, selama ini yang umum dipergunakan dalam perusahaan adalah pengukuran kinerja tradisional yang hanya menitikberatkan pada sektor keuangan saja. Pengukuran kinerja dengan sistem ini menyebabkan orientasi perusahaan hanya pada keuntungan jangka pendek dan cenderung mengabaikan kelangsungan hidup perusahaan dalam jangka panjang. Karena kurang mampu mengukur kinerja harta-harta tak tampak (intangible assets) dan harta-harta intelektual (sumber daya manusia) perusahaan.

Selain itu pengukuran kinerja dengan cara ini juga kurang mampu bercerita banyak mengenai masa lalu perusahaan, kurang memperhatikan sektor eksternal, serta tidak mampu sepenuhnya menuntun perusahaan ke arah yang lebih baik (Kaplan dan Norton, 1996:7).

Dewasa ini, disadari bahwa pengukuran kinerja keuangan yang digunakan oleh banyak perusahaan untuk mengukur kinerja eksekutif tidak lagi memadai, sehingga dikembangkan suatu konsep "Balanced Scorecard." Balanced scorecard adalah suatu konsep pengukuran kinerja bisnis yang diperkenalkan oleh Robert S. Kaplan (Guru Besar Akuntansi di Harvard Business School) dan David P. Norton (Presiden dari Renaissance Solutions, Inc.). Konsep ini menyeimbangkan pengukuran atas kinerja sebuah organisasi bisnis yang selama ini dianggap terlalu condong pada kinerja keuangan.

Dari keseluruhan kegiatan yang dilakukan oleh sebuah perusahaan pada akhirnya akan bermuara pada nilai yang akan diberikan oleh pelanggan mengenai kepuasan yang dirasakan. Kepuasan merupakan tingkat perasaan dimana seseorang menyatakan hasil perbandingan atas kinerja produk (jasa) yang diterima dan yang diharapkan (Kotler, 1997).

Secara umum, terdapat empat macam kinerja bisnis yang diukur dalam Balanced Scorecard, yaitu:

1. Perspektif keuangan (financial perspective)

2. Perspektif nasabah/konsumen (customer perspective)

3. Perspektif proses internal bisnis (intenal business process perspective)

4. Perspektif pembelajaran dan pertumbuhan (learning and growth perspective)

Konsep pengukuran kinerja Balanced Scorecard memiliki keistimewaan dalam hal cakupan pengukurannya yang komprehensif, karena selain mempertimbangkan kinerja finansial, juga mempertimbangkan pula kinerja-kinerja non finansial. Selain itu Balanced Scorecard tidak hanya mengukur aktivitas akhir (out come) tetapi juga aktivitas-aktivitas penentu hasil akhir (driver). Namun dalam penelitian ini yang diteliti hanyalah satu (1) aspek yakni perspektif pelanggan.

Balanced Scorecard dapat diterapkan pada organisasi bisnis yang menghasilkan produk maupun jasa. Namun dalam penelitian ini yang dijadikan sebagai objek adalah organisasi jasa yang bergerak dalam bidang keuangan, yaitu bank. Sesuai dengan Undang-Undang No.10 Tahun 1998 tentang Perubahan atas Undang-Undang Nomor 7 Tahun 1992 tentang Perbankan, yang dimaksud dengan bank adalah badan usaha yang menghimpun dana dari masyarakat dalam bentuk simpanan dan menyalurkannya kepada masyarakat dalam bentuk kredit dan atau bentuk-bentuk lainnya dalam rangka meningkatkan taraf hidup rakyat banyak.

Dalam era globalisasi ini, perusahaan akan selalu menyadari pentingnya faktor pelanggan. Oleh karena itu, mengukur tingkat kepuasaan para 
pelanggan sangatlah perlu, walaupun hal tersebut tidaklah semudah mengukur berat badan atau tinggi badan pelangggan yang bersangkutan.

Banyak manfaat yang diterima oleh perusahaan dengan tercapainya tingkat kepuasaan pelanggan yang tinggi. Tingkat kepuasaaan pelanggan yang tinggi dapat meningkatkan loyalitas pelanggan dan mencegah perputaran pelanggan, mengurangi sensitivitas pelanggan terhadap harga, mengurangi biaya kegagalan pemasaran, mengurangi biaya operasi yang diakibatkan oleh meningkatnya jumlah pelanggan, meningkatkan efektivitas iklan, dan meningkatkan reputasi bisnis (Fornell, 1992).

Berdasarkan undang-undang
tersebut, lembaga keuangan bank dibedakan menjadi dua yaitu Bank Umum dan Bank Perkreditan Rakyat. Adapun kegiatan bank di Indonesia terutama kegiatan Bank Umum adalah menghimpun dana dari masyarakat (funding), menyalurkan dana ke masyarakat (lending), serta memberikan jasa-jasa bank lainnya (services).

PT Bank Negara Indonesia (Persero) Tbk. merupakan salah satu bank milik pemerintah (BUMN) yang mempunyai visi "Menjadi Bank Kebanggaan Nasional yang Unggul, Terkemuka dan Terdepan dalam Layanan dan Kinerja."

Konsep Balanced Scorecard membantu memberikan rerangka komprehensif untuk menerjemahkan visi ke dalam sasaran-sasaran strategik. Berdasarkan pada sistem pengukuran kinerja Balanced Scorecard ini, Kaplan juga mengungkapkan pentingnya melihat aspekaspek di luar aspek keuangan dalam rangka mencapai keseimbangan dalam pengukuran kinerja. Usaha ini berkaitan dengan pihak-pihak di dalam dan di luar organisasi yang digunakan sebagai tolak ukur guna mengimbangi scorecard yang berdimensi profitabilitas, contohnya aspek kepuasan nasabah, kualitas produk atau jasa, loyalitas karyawan dan sebagainya.
PT. Bank BNI telah menggunakan Balanced Scorecard sejak tahun 2006 di mana manajemen Bank BNI berharap dengan adanya konsep pengukuran kinerja yang menyeluruh tersebut Bank BNI dapat lebih terpacu untuk ditingkatkan.

Namun, dari berbagai layanan maupun fasilitas yang diberikan Bank BNI, serta pengukuran kinerja menggunakan balanced scorecard belum dapat dijadikan sebagai indikator mutlak Bank BNI untuk dapat menduduki posisi perbankan terbaik di Indonesia dalam hal pelayanan kepada nasabah.

Hal tersebut dapat dilihat dalam sebuah survey The Best Bank Service Excellence 2008-2012 yang dilakukan oleh Marketing Research Indonesia (MRI) - Managing Director MRI Ermina Yuliarti menjelaskan bahwa seperti pada survei tahun sebelumnya, dalam pengukuran BSEM ini, menggunakan seorang shopper yang bertindak sebagai nasabah. Mereka membuka rekening tabungan, meminta informasi mengenai produk bank, melakukan berbagai transaksi finansial, melakukan komplain mengenai transaksinya, menelepon customer service untuk menanyakan suatu transaksi, dan menutup rekening.

Metodologi yang digunakan MRI adalah mystery shopping. Tahun 2012 merupakan ke-16 kalinya MRI melakukan pengukuran kualitas layanan perbankan

Bank Service Excellence Monitor (BSEM). Misi pengukurannya adalah untuk memacu industri perbankan agar memberikan pelayanan yang terbaik bagi nasabah BSEM ini juga melibatkan pengamatan pada sarana penunjang, seperti gedung, penyediaan berbagai fasilitas dan kondisinya, seperti toilet dan ATM. Fungsi shopper dalam pengumpulan data adalah untuk merekam apa yang mereka amati dan alami sehingga hasilnya bersifat objektif. Oleh karena itu parameter-parameter layanan dibuat agar bersifat tangible atau nyata, bisa diamati pancaindera, obyektif 
dan menghindarkan pengamatan shopper yang bersifat persepsi atau pendapat.

Berdasarkan hasil survey yang telah dilakukan oleh Marketing Research Indonesia (MRI) tersebut, dapat diketahui bahwa Bank BNI belum pernah menduduki posisi peringkat 1 dalam 10 perbankan terbaik, dalam pemberian pelayanan prima kepada para nasabahnya. BNI merupakan perusahaan perbankan yang corporate, namun dalam hal palayanan prima setiap kantor cabang ataupun kantor layanan mempunyai kebijakan tersendiri. Sehingga dalam pelaksanaan indikator kepuasan pelanggan, BNI tiap cabang ataupun tiap kantor layanan berbeda.

Penelitian ini ditunjukkan utuk mengkaji kinerja perusahaan berdasarkan hasil pengukuran kinerja non keuangan PT. Bank Negara Indonesia (Persero) Tbk. Kantor Layanan UPI Bandung dan Kantor Layanan Ganesha Bandung melalui perspektif pelanggan dari Balanced Scorecard.

\section{Landasan Teori}

Pada dasarnya tujuan yang ingin diwujudkan oleh perusahaan adalah penciptaan kekayaan. Oleh karena itu, perusahaan dapat disebut sebagai institusi penciptaan kekayaan (wealth-creating institution). Bahkan lebih jauh dari itu, dalam memasuki lingkungan bisnis yang kompetitif, perusahaan dituntut untuk menjadi institusi pelipat ganda kekayaan (wealth-multiplying institution) untuk dapat bertahan dan bertumbuh dalam lingkungan bisnis yang didalamnya customer memegang kendali bisnis, perusahaan dapat membedakan dirinya dalam persaingan.

Kinerja merupakan suatu istilah yang secara umum digunakan untuk sebagian atau seluruh tindakan atau aktivitas dari pegawai atau organisasi pada suatu periode dengan referensi pada sejumlah standar yang ditetapkan seperti biaya-biaya masa lalu atau yang diproyeksikan, dengan dasar efisiensi, pertanggungjawaban atau akuntabilitas manajemen dan semacamnya.

Kinerja perusahaan hendaknya merupakan hasil yang dapat diukur dan menggambarkan kondisi empirik suatu perusahaan dari berbagai ukuran yang disepakati. Pengukuran kinerja merupakan kunci penting dalam infrastruktur organisasi. Istilah tersebut mencangkup satu set kebijakan operasional, sistem, dan praktek yang mengkondisikan tindakan serta transfer informasi untuk mendukung seluruh sistem manajemen.

Fenomena yang terjadi adalah banyaknya perusahaan yang mencoba untuk meningkatkan kinerja yang ada dengan menekankan biaya dan peningkatan kualitas, namun tidak mengidentifikasikan proses mana yang benar-benar berarti dan strategis bagi perusahaan. Artinya, perusahaan perlu mengidentifikasikan hal-hal yang perlu ditingkatkan sehingga strategi perusahaan dapat berjalan dengan sukses.

Dalam menilai kinerja perusahaan, yang selama ini terjadi hanya ditinjau dari aspek keuangan yang ternyata hanya berorientasi pada keuntungan jangka pendek dan cenderung mengabaikan kelangsungan hidup perusahaan jangka panjang. Sistem pengukuran kinerja yang demikian sudah tidak memadai lagi bagi pengukuran kinerja saat ini, dimana lingkungan persaingan bergerak dengan yang akan datang untuk meningkatkan kinerja perusahaan.

Melalui Balanced Scorecard, perusahaan mengukur kegiatan penciptaan nilai masa depan dengan tetap mempertimbangkan kepentingankepentingan masa yang akan datang, mengukur apa yang telah diinvestasikan dalam pengembangan sumber daya manusia, sistem dan prosedur demi perbaikan kinerja di masa yang akan datang. Balanced Scorecard merupakan konsep manajemen yang diperkenalkan oleh Robert Kaplan pada tahun 1992, sebagai pengembangan dari konsep 
pengukuran kinerja (performance measurement) untuk sebuah perusahaan. Balanced Scorecard mempertahankan perspektif keuangan karena pengukuran kinerja berguna dalam mengikhtisarkan konsekuensi tindakan ekonomi terukur yang telah diambil.

Konsep ini memperkenalkan suatu sistem pengukuran kinerja perusahaan dengan menggunakan kriteria-kriteria tertentu. Kriteria tersebut sebenarnya merupakan penjabaran dari apa yang menjadi misi dan strategi perusahaan dalam jangka panjang, yang digolongkan menjadi empat perspektif yang berbeda yaitu :

1. Perspektif keuangan, yaitu bagaimana perusahaan berorientasi pada para pemegang saham

2. Perspektif pelanggan (customer), yaitu bagaimana perusahaan dapat menjadi supplier utama yang paling bernilai bagi customer

3. Perspektif proses bisnis internal, yaitu proses bisnis apa saja yang terbaik yang harus dilakukan perusahaan dalam jangka panjang maupun jangka pendek untuk mencapai tujuan keuangan dan kepuasan pelanggan

4. Perspektif pembelajaran dan pertumbuhan, yaitu bagaimana perusahaan dapat meningkatkan dan menciptakan value secara terus menerus, terutama dalam hubungannya dengan kemampuan dan motivasi karyawan.

Keempat perspektif tersebut menjadi satu kesatuan yang tidak dapat dipisahkan. Keempat perspektif tersebut juga merupakan indikator pengukuran kinerja yang saling melengkapi dan saling memiliki hubungan sebab akibat.

$$
\text { Perspektif pelanggan dalam }
$$

Balanced Scorecard melihat aspek pelanggan memainkan peranan penting dalam kehidupan perusahaan. Sebuah perusahaan yang tumbuh dan tegar dalam persaingan tidak akan mungkin survive apabila tidak didukung oleh pelanggan. Loyalitas tolok ukur pelanggan dilakukan dengan terlebih dahulu melakukan pemetaan terhadap segmen pasar yang akan menjadi target atau sasaran. Apa yang menjadi keinginan dan kebutuhan para pelanggan menjadi hal yang penting dalam perspektif ini.

Pada kinerja non keuangan penelitian ini mengkaji hasil pengukuran kinerja. Dalam perspektif pelanggan yang menggunakan pengukuran kepuasan nasabah. Melalui pengukuran kepuasan konsumen digunakan untuk mengetahui sejauh mana derajat kualitas pelayanan PT Bank Negara Indonesia (Persero) Tbk. Kantor Layanan UPI Bandung dan Kantor Layanan Ganesha Bandung kepada nasabahnya.

\section{Metode Penelitian}

Penelitian ini bertujuan untuk memperoleh gambaran atau deskripsi mengenai kinerja non-keuangan menggukan perspektif pelanggan dari Balanced Scorecard pada BNI KLN UPI dan BNI KLN Ganesha. Berdasarkan tujuan tersebut, jenis penelitian yang digunakan dalam penelitian ini adalah penelitian deskriptif. M. Nazir (2005:89) menyebutkan bahwa "penelitian deskriptif adalah studi untuk menentukan fakta dengan interprestasi yang tepat". Dalam studi deskriptif ini, juga termasuk studi untuk melukiskan secara akurat sifat-sifat dari fenomena, kelompok atau individu, dan studi untuk menentukan frekuensi terjadinya suatu keadaan untuk meminimalisasikan bisa dan memaksimumkan realibilitas, yang akan diperlukan untuk penelitian selanjutnya.

Dalam pengumpulan data, penelitian ini menggunakan data primer yang langsung diperoleh dari responden yang diteliti dengan menggunakan metode survey/kuesioner. Menurut Kerlinger (dalam Sugiyono 2005:7), penelitian survey adalah 'penelitian yang dilakukan oleh populasi besar maupun kecil, tetapi data-data yang dipelajari adalah data dari sampel yang diambil dari populasi tersebut, sehingga ditemukan kejadian-kejadian relatif, 
distributif, dan hubungan-hubungan antar variabel sosiologis maupun psikologis. Sugiyono (2005:7) menambahkan, "pada umumnya metode survey dilakukan untuk mengambil suatu generalisasi dari pengamatan yang tidak terlalu mendalam".

Berkaitan dengan jenis penelitian, maka jenis penelitian ini adalah penelitian positivism/kuantitatif dan metode yang digunakan adalah metode deskriptif dengan pendekatan survey yaitu hasil penelitian yang kemudian diolah dan dianalisis untuk diambil kesimpulannya. Dengan menggunakan metode penelitian ini akan diketahui gambaran yang jelas mengenai variabel yang diteliti dan kebenaran dalam sesuatu bidang yang telah ada, sehingga menghasilkan kesimpulan yang akan memperjelas gambaran mengenai variabel penelitian.

\section{a. Populasi dan Sampel}

Populasi dalam penelitian ini adalah nasabah pada PT. Bank Negara Indonesia (Persero) Tbk Kantor Layanan UPI Bandung yang berada di jalan Setiabudhi dan pada PT. Bank Negara Indonesia (Persero) Tbk Kantor Layanan Ganesha Bandung yang berada di jalan Tamasari. Adapun yang menjadi objek penelitian adalah yang telah menjadi nasabah PT. Bank Negara Indonesia (Persero) Tbk Kantor Layanan UPI Bandung yang berjumlah 60.839 nasabah dan Kantor Layanan Ganesha Bandung yang berjumlah 28.895 nasabah.

Sedangkan sampel yang diinginkan menggunakan rumus Slovin dalam Husein Umar (1997:74).

$$
\mathrm{n}=\frac{\mathrm{N}}{1+\mathrm{Ne}^{2}}
$$

Di mana:

$$
\begin{aligned}
\mathrm{n}= & \text { Ukuran sampel } \\
\mathrm{N}= & \text { Ukuran populasi } \\
\mathrm{e}= & \text { Prosentase kelonggaran } \\
& \text { ketelitian karena kesalahan } \\
& \text { pengambilan sample yang } \\
& \text { masih dapat ditolelir yaitu } 10 \%
\end{aligned}
$$

(karena populasi termasuk besar)

Dengan demikian diperoleh hasil perhitungan untuk nasabah BNI Kantor Layanan UPI Bandung sebagai berikut:

$$
\mathrm{n}=\frac{60,839}{1+60,839(10 \%)^{2}}
$$

$\mathrm{n}$

= 99,6723 (dibulatkan 100 sampel nasabah BNI KLN UPI)

Sedangkan untuk perhitungan sampel nasabah BNI KLN Ganesha Bandung diperoleh hasil sebagai berikut :

$$
\mathrm{n}=\frac{28,895}{1+28,895(10 \%)^{2}}
$$

$\mathrm{n}$

= 99.6551 (dibulatkan 100 sampel nasabah BNI KLN Ganesh

\section{b. Teknik Pengumpulan Data}

Data dikumpulkan dengan menngunakan angket (kuesioner). Kuesioner diambil dari Standar Layanan Bank BNI yang disesuaikan dengan konsep TERRA (Tangible, Empathy, Responsiveness, Reliability, Assurance) yang dipopulerkan oleh Frontier Consultan.

\section{c. Teknik Analisa Data}

Menurut Hasan, M.I (2002:54) "pengujian hipotesis adalah suatu prosedur yang akan menghasilkan suatu keputusan, yaitu keputusan menerima atau menolak hipotesis ini". Hipotesis yang akan diuji dalam penelitian ini berkaitan dengan kinerja non-keuangan menggunakan perspektif pelanggan dari Balanced Scorecard pada BNI Kantor Layanan UPI Bandung dan Kantor Layanan Ganesha Bandung.

\section{d. Uji Hipotesis Komparatif}

Dalam pengujian hipotesis komparatif, penelitian menggunakan uji beda ( $t$-test). Menurut Sugiyono (2009:119), "Statistik parametris yang digunakan untuk menguji hipotesis komparatif rata-rata dua sampel bila datanya berbentuk interval atau rasio adalah menggunakan $t$-test'. Pengujian ini dilakukan untuk menguji parameter khusus dari populasi yang berbentuk perbandingan atau untuk menguji kemampuan generalisasi (signifikasi hasil 
penelitian) yang berupa perbandingan keadaan variabel dari dua kelompok sampel.

Dalam menggunakan statistik parametris harus memenuhi asumsi bahwa variabel yang dianalisis berdistribusi normal dan homogency. Dalam t-test terdapat beberapa rumus yang dapat digunakan dalam pengujian hipotesis. Sugiyono (2009:196) merumuskan rumus $t$-test beserta pedoman penggunaannya sebagai berikut :

1. Bila jumlah anggota sampel $n 1=n 2$, dan varian homogen $\sigma_{1}^{2}=\sigma_{2}^{2}$, maka dapat digunakan rumus $t$-test baik untuk separated, maupun bentuk pooled varian. untuk melihat harga $\mathrm{t}$ tabel digunakan $\mathrm{dk}=\mathrm{n} 1+\mathrm{n} 2-2$

2. Bila $\mathrm{n} 1 \neq \mathrm{n} 2$, dan varian homogen $\sigma_{1}^{2}=$ $\sigma_{2}^{2}$, maka dapat digunakan rumus t-test dengan pooled varian. Derajat kebebasan $(\mathrm{dk})=\mathrm{n} 1+\mathrm{n} 2-2$

3. Bila $\mathrm{n} 1=\mathrm{n} 2$, dan varian tidak homogen $\sigma_{1}^{2} \neq \sigma_{2}^{2}$, maka dapat digunakan rumus t-test dengan separated dan pooled varian. Dengan $\mathrm{dk}=\mathrm{n} 1-1$ atau $\mathrm{n} 2-1$. Jadi dk bukan $\mathrm{n} 1+\mathrm{n} 2-2$.

4. Bila $\mathrm{n} 1 \neq \mathrm{n} 2$, dan varian tidak homogen $\sigma_{1}^{2} \neq \sigma_{2}^{2}$, maka dapat digunakan rumus $t$-test dengan separated varian. Harga $t$ sebagai pengganti $t$ tabel dihitung dari selisih harga t tabel dengan $(\mathrm{dk})=(\mathrm{n} 1-$ 1) atau (n2 - 1) dibagi dua, dan kemudian ditambahkan dengan harga $t$ yang terkecil.

5. Bila sampel berkorelasi/berpasangan sebelum dan sesudah treatment atau perlakuan, atau membandingkan kelompok kontrol dengan kelompok eksperimen digunakn t-test sampel related.

Rumus - rumus uji t (t-test) :

$t$

$=\frac{\bar{x}_{1}-\bar{x}_{2}}{\sqrt{\frac{s_{1}^{2}}{n_{1}}+\frac{s_{2}^{2}}{n_{2}}}}$ $t$

$=\frac{\bar{x}_{1}-\bar{x}_{2}}{\sqrt{\frac{\left(n_{1}-1\right) s_{1}^{2}\left(n_{2}-1\right) s_{2}^{2}}{n_{1}+n_{2}-2}\left(\frac{1}{n_{1}}+\frac{1}{n_{2}}\right)}}$

Pooled Varian

$t$

$=\frac{\bar{x}_{1}-\bar{x}_{2}}{\sqrt{\left(\frac{s_{1}^{2}}{n_{1}}\right)+\left(\frac{s_{2}^{2}}{n_{2}}\right)-2 r\left(\frac{s_{1}}{\sqrt{n_{1}}}\right)\left(\frac{s_{2}}{\sqrt{n}_{2}}\right)}}$

Sampel Berpasangan

Kesimpulan :

a. Jika $t_{\text {hitung }}<t_{\text {tabel }}$ maka $\mathrm{H}_{\mathrm{o}}$ diterima

b. Jika $t_{\text {hitung }}<\mathrm{t}_{\text {tabel }}$ maka $\mathrm{H}_{\mathrm{a}}$ diterima

Sebelum diadakan pengambilan keputusan apakah hipotesis diterima atau ditolak, maka terlebih dahulu hipotesis nol dan hipotesis alternatif diformulasikan dengan tujuan untuk mengetahui ada tidaknya perbedaan antara kelompok sampel yang diteliti. Hipotesis nol $\left(\mathrm{H}_{\mathrm{o}}\right)$ yaitu hipotesis yang menjelaskan tentang tidak adanya perbedaan antara kedua kelompok sampel, sedangkan hipotesis alternatif $\left(\mathrm{H}_{\mathrm{a}}\right)$ merupakan hipotesis standar. Adapun hipotesis tersebut adalah :

a. $H_{0}: \mu_{1}=\mu_{1}=$ BNI KLN UPI Bandung tidak memiliki perbedaan kinerja non-keuangan menggunakan perspektif pelanggan Balanced Scorecard dengan BNI KLN Ganesha Bandung.

b. $\mathrm{H}_{\mathrm{a}}: \mu_{1} \neq \mu_{1}=\mathrm{BNI}$ KLN UPI Bandung memiliki perbedaan kinerja nonkeuangan menggunakan perspektif pelanggan Balanced Scorecard dengan BNI KLN Ganesha Bandung.

Berdasarkan kaidah pengujian hipotesis Separated statistitik yang diajukan, apabila nilai perhitungan menunjukkan $\mu_{1}=\mu_{1}$ maka $\mathrm{H}_{\mathrm{o}}$ diterima, dan apabila nilai perhitungan menunjukkan $\mu_{1} \neq \mu_{1}$ maka $\mathrm{H}_{\mathrm{o}}$ ditolak yang artinya $\mathrm{Ha}$ diterima. 


\section{Hasil dan Pembahasan}

Berdasarkan hasil perhitungan kepuasan pelanggan pada BNI KLN UPI dan BNI KLN Ganesha keduanya tidak mencapai target yang ditetapkan oleh BNI Perguruan Tinggi Bandung. Hal ini bisa terlihat bahwa target yang harus dicapai pada tahun 2012 sebesar 95\%, namun kepuasan pelanggan yang dicapai oleh $\mathrm{BNI}$ KLN UPI adalah sebesar $79,05 \%$ dan kepuasan pelanggan yang dicapai oleh BNI KLN Ganesha adalah sebesar $75,48 \%$. Disini dapat terlihat bahwa BNI KLN UPI dan BNI KLN Ganesha tidak mencapai target yang diharapkan. Dalam hal ini banyak faktor yang mempengaruhinya, diantaranya adalah penelitian ini dilaksanakan sebelum tutup tahun 2012 sedangkan BNI KLN UPI dan BNI KLN Ganesha Bandung biasanya melakukan penilaian kepuasan pelanggan setelah tutup tahun, selain itu dalam penentuan sample yang ditentukan oleh BNI KLN UPI dan KLN Ganesha berbeda dengan yang ditentukan oleh peneliti, dimana peneliti menentukan jumlah sampel menggunakan rumus slovin sedangkan BNI KLN UPI dan BNI KLN Ganesha menggunakan perkiraan misal 40 sampel dari jumlah keseluruhan nasabah.

Sedangkan berdasarkan pengujian hipotesis dengan uji-t diketahui bahwa tidak terdapat perbedaan yang signifikan antara kepuasan nasabah BNI KLN UPI dengan kepuasan pelanggan BNI KLN Ganesha hal tersebut dapat diketahui dari sig 2-tailed > $0,05(0,686>0,05)$, yang artinya BNI KLN UPI dan BNI KLN Ganesha tidak memiliki perbedaan dalam hal kepuasan pelanggan.

Berdasarkan pengujian yang telah dilakukan, hal tersebut dapat diketahui dari penjelasan perindikator berikut ini :

1. Analisis terhadap indikator berwujud (tangible), hasil yang dicapai untuk BNI KLN UPI adalah $75,12 \%$, sedangkan BNI KLN Ganesha adalah 74,96\%. Maka terlihat bahwa kepuasan pelanggan terhadap indikator tangible lebih tinggi di BNI KLN UPI dibanding BNI KLN Ganesha walaupun perbedaannya tidak signifikan. Dalam menilai indikator tangible ini nasabah menilai BNI dari segi ruang tunggu pelayanan, loket pelayanan, dan penampilan petugas pelayanan BNI.

2. Analisis terhadap indikator empati (empathy), hasil yang dicapai untuk BNI KLN UPI adalah 92,6\%, sedangkan BNI KLN Ganesha adalah 76,6\%. Maka terlihat bahwa kepuasan pelanggan terhadap indikator empathy lebih tinggi di BNI KLN UPI dibanding BNI KLN Ganesha dengan perbedaan yang signifikan. Dalam menilai indikator empathy ini nasabah menilai BNI dari segi perhatian petugas pelayanan, kepedulian petugas, dan keramahan petugas pelayanan BNI.

3. Analisis terhadap indikator kehandalan (reliability), hasil yang dicapai untuk BNI KLN UPI adalah 73,4\%, sedangkan BNI KLN Ganesha adalah 73,27\%. Maka terlihat bahwa kepuasan pelanggan terhadap indikator reliabillity lebih tinggi di BNI KLN UPI dibanding BNI KLN Ganesha walaupun perbedaannya tidak signifikan. Dalam menilai indikator reliability ini nasabah menilai dari segi keandalan petugas dalam memberikan informasi pelayanan, keandalan petugas dalam melancarkan prosedur pelayanan, dan keandalan petugas dalam memudahkan teknis pelayanan.

4. Analisis terhadap indikator daya tanggap (responsiviness), hasil yang dicapai untuk BNI KLN UPI adalah $82,4 \%$, sedangkan BNI KLN Ganesha adalah $82,06 \%$. Maka terlihat bahwa kepuasan pelanggan terhadap indikator responsiveness lebih tinggi di BNI KLN UPI dibanding BNI KLN Ganesha walaupun perbedaannya tidak signifikan. Dalam menilai indikator responsiveness nasabah menilai dari segi respon petugas pelayanan terhadap keluhan nasabah, respon petugas pelayanan terhadap saran nasabah, dan respon petugas pelayanan terhadap kritikan nasabah.

5. Analisis terhadap indikator jaminan (assurance), hasil yang dicapai untuk 
BNI KLN UPI adalah 78,8\%, sedangkan BNI KLN Ganesha adalah 78,1\%. Maka terlihat bahwa kepuasan pelanggan terhadap indikator assurance lebih tinggi di BNI KLN UPI dibanding BNI KLN Ganesha walaupun perbedaannya tidak signifikan. Dalam menilai indikator assurance nasabah menilai dari segi kemampuan administrasi petugas pelayanan, kemampuan teknis petugas pelayanan, dan kemampuan sosial pelayanan.

Maka secara garis besar, kepuasan pelanggan BNI KLN UPI dan BNI KLN Ganesha apabila dilihat dari sudut pandang per indikator, kepuasan pelanggan BNI KLN UPI lebih tinggi daripada BNI KLN Ganesha. Namun secara perhitungan $t$ test sample independent tidak ada perbedaan antara keduanya. Hal ini disebabkan oleh beberapa faktor diantaranya : karakteristik objek yang sama, karakteristik responden yang sama, dan memiliki standar pelayanan yang sama.

Dan apabila kita kaitkan hasil penelitian ini, dalam era globalisasi saat ini persaingan bisnis menjadi sangat tajam, baik di pasar domestik maupun di pasar internasional. Untuk memenangkan persaingan, perusahaan harus mampu memberikan kepuasan kepada pelanggannya, karena kepuasan pelanggan akan berdampak pada pangsa pasar perusahaan, dimana tujuan akhir perusahaan adalah untuk mendapatkan laba. Dengan kenaikan pangsa pasar akan berdampak pada peningkatan kinerja keuangan perusahaan. Oleh karena itu, demi tercapainya peningkatan kinerja keuangan perusahaan maka perusahaan harus meningkatkan pula kepuasan pelanggannya. Sesuai dengan teori Balanced Scorecard bahwa dalam upaya mencapai kinerja keuangan yang diharapkan, perusahaan harus mampu meningkatkan kinerja non-keuangan yang terdiri dari perspektif pembelajaran dan pertumbuhan, perspektif proses bisnis internal dan perspektif pelanggan.

\section{Kesimpulan dan Saran}

\section{Kesimpulan}

Dari hasil analisis penelitian mengenai perbandingan kinerja non keuangan menggunakan perspektif Balanced Scorecard pada BNI KLN UPI dan BNI KLN Ganesha Bandung, maka dapat ditarik kesimpulan sebagai berikut :

1. Pengukuran Kinerja Non Keuangan menggunakan perspektif pelanggan Balanced Scorecard, yaitu melalui pengukuran kepuasan pelanggan. Untuk kepuasan pelanggan pada BNI KLN UPI maupun BNI KLN Ganesha Bandung tidak mencapai target yang ditetapkan oleh BNI cabang. Untuk target kepuasan pelanggan tahun 2012 adalah 95\% namun untuk kepuasan pelanggan yang dicapai oleh BNI KLN UPI dan BNI KLN Ganesha Bandung masing-masing $79,05 \%$ dan $75,48 \%$.

2. Dari hasil analisis perbandingan yang telah dilakukan yakni untuk membuktikan perbedaan Kinerja Non Keuangan menggunakan perspektif pelanggan Balanced Scorecard pada BNI KLN UPI dan BNI KLN Ganesha dapat disimpulkan bahwa tidak terdapat perbedaan yang signifikan antara kepuasan pelanggan pada BNI KLN UPI dengan kepuasan pelanggan BNI KLN Ganesha.

\section{Saran}

Berdasarkan hasil analisis penelitian mengenai perbandingan kinerja non keuangan menggunakan perspektif Balanced Scorecard pada BNI KLN UPI dan BNI KLN Ganesha Bandung, maka peneliti memberikan saran sebagai berikut :

1. Dalam indikator tangible, BNI perlu memperhatikan kenyamanan nasabah ketika berada di BNI. Salah satunya adalah dengan cara meningkatkan fasilitas yang sudah tersedia, misal ruang tunggu pelayanan dan loket pelayanan didesain senyaman mungkin. Selain itu juga grooming atau penampilan petugas perlu diperhatikan 
sesuai dengan SOP yang ditetapkan oleh BNI. Jika terdapat penyimpangan dalam penampilan, sebaiknya perlu ditindaklanjuti oleh pimpinan BNI.

2. Dalam indikator empathy, petugas BNI diharapkan untuk lebih intens dalam memberikan perhatian dan keramahan kepada nasabah sehingga mereka merasa tidak diabaikan ketika berada disana. Dan perlakuan tersebut merupakan bukti kepedulian petugas BNI terhadap nasabahnya.

3. Dalam indikator reliability, petugas BNI diharapkan lebih menguasai informasi dasar (basic information) mengenai prosedur dan teknis pelayanan perbankan.

4. Dalam indikator responsiveness, petugas BNI diharapkan lebih cepat tanggap terhadap keluhan yang disampaikan oleh nasabah. Sehingga nasabah tidak merasa kecewa yang akan memberikan kesan negatif terhadap BNI.

5. Dalam indikator assurance, petugas BNI diharapkan dapat memunculkan kepercayaan dari nasabah BNI. Hal ini dapat terwujud apabila petugas BNI memiliki keterampilan dalam teknis pelayanan kepada nasabah.

Apabila semua indikator tersebut dilakukan dengan baik dan tepat, maka dapat dipastikan nasabah akan merasa puas dengan pelayanan yang diberikan oleh pihak BNI. Dengan demikian target kepuasan nasabah yang diharapkan dapat tercapai.

\section{Daftar Pustaka}

Buku :

Ali, Lukman. (1991). Kamus Besar Bahasa Indonesia. Jakarta : Depdikbud dan Balai Pustaka.

Bahasa Indonesia. Jakarta :
Depdikbud dan Balai Pustaka.
Amin Widjaja Tunggal.(2001). Pengukuran Kinerja dengan Balanced Scorecard. Jakarta: Harvinda.
Berry dan Zeithaml, dikutip oleh Handi Irawan,( 2003), Manajemen Pemasaran, Bandung.

Drucker, Peter F. (1982). Pengantar Manajemen. Jakarta: PT Pustaka Binaman Pressindo.

Fandy Tjiptono, 2000, Strategi Pemasaran, Andi Offset, Yogyakarta.

--------.-. (2005). Prinsip-Prinsip Total Quality Service (TQS). Yogyakarta : Andi.

J. Supranto,M.A.,APU. (2011). Pengukuran Tingkat Kepuasan Pelanggan Untuk Menaikkan Pangsa Pasar. Jakarta : Rineka Cipta.

Kaplan, Robert S, Norton, David P. (1996) The Balanced Scorecard, Translating Strategy into Action, Harvard Business Press, Boston.

Kaplan Robert S. and David P. Norton., (2001). Balanced Scorecard Menerapkan Strategi Menjadi Aksi. Terjemahan. Jakarta: Erlangga.

Kasmir, SE, MM, (2003), Bank dan Lembaga Keuangan Lainnya. Edisi Enam., Jakarta: PT Raja Grafindo Persada .

Mulyadi. (2001). Alat Manajemen Konteporer untuk Pelipatganda Kinerja Keuangan Perusahaan Balanced

Scorecard.Jakarta:Salemba Empat.

Mulyadi dan Setiawan, J.. (2001). Sistem Perencanaan dan Pengendalian Manajemen. Jakarta : Salemba Empat.

Malayu S.P. Hasibuan. (2009). DasarDasar Perbankan.Jakarta: Bumi Aksara

Nasution. (2004). Metode Research. Jakarta:Bumi Aksara.

Rahmayanti, N. (2010). Manajemen Pelayanan Prima. Yogyakarta: Graha IImu.

Riduwan. (2008). Dasar-Dasar Statistika. Bandung;: Alfabeta. 
Riduwan. (2004), Metode dan Teknik Menyusun Tesis, Bandung.: Alfabeta.

\section{--------. (2010). Metode dan Tehnik Menyususn Tesis. Bandung: Alfabeta. \\ Sugiyono, Prof. Dr. (1999). Metode Penelitian Bisnis. Bandung: CV Alfabeta.}

(2004). Metode Penelitian Bisnis. Bandung : Alfabeta. ---------------. (2005). Memahami Penelitian Kualitatif.Bandung : Alfabeta. (2007). Metode Penelitan Kuantitatif, Kualitatif dan $R \& D$. Bandung: Alfabeta.

(2008), Metode Penelitian Bisnis.Bandung : Alfabeta.

(2009). Metode Penelitian Kuantitatif Kualitatif dan $R \& D$. Bandung : Alfabeta.

Tangkilan, Hessel Nogi. S. (2003). Manajemen Modern untuk Sektor Publik:Strategic Management, Total Quality, Balanced Scorecard, Scenario Planning. Yogyakarta : Balairung \& Company.

Umar, Husein, (2004), Evaluasi Kinerja Perusahaan. PT. Gramedia Pustaka Utama, Jakarta.

Yuwono, Sony dan kawan-kawan. (2003). Petunjuk Praktis Penyusunan Balanced Scorecard Menuju Organisasi yang Berfokus pada Strategi. Jakarta : PT. Gramedia Pustaka Utama.

Zeinhaml, Valerie A,Mary Jo Bitner, Dyayne. D. Gremler. (2009). Service Marketing (Integrating Customer Focus Accros the Firm).

Internet:

Wheelen and Hunger, (2000). Kinerja Perusahaan Diukur dengan Balanced Scorecard [Online].
Tersedia

http://www.balancedscorecard.com . [28 Maret 2012].

Willie and Shirley, (1997). Kinerja Perusahaan Diukur dengan Balanced Scorecard Scorecard [Online]. Tersedia http://www.balancedscorecard.com . [28 Maret 2012].

Hasil Survey The Best Bank Service Excellence 2008-2012 Marketing Research Indonesia (MRI) [online]. Tersedia http://www.infobanknews.com. [28 Maret 2012].

Suhendra, Maman, (2004), Evaluasi Atas Penerapan Balanced Scorecard Sebagai Sistem Pengukuran Kinerja Perusahaan, [Online] Tersedia : http://www.balancedscorecard.com . [28 Maret 2012].

\section{Sumber Lainnya :}

Rosyati dan Hidayati, (2004), Pengukuran Kinerja Perusahaan dengan Balanced Scorecard (Studi Kasus pada Perusahaan Daerah Air Minum Kota Magelang).Tidak Diterbitkan.

Lestari,U.P dan Darmawati Dwita, (2003), Penilaian Kinerja Organisasi melalui Pendekatan Balanced Scorecard (studi pada Program Studi Manajemen Fakultas Ekonomi Universitas Jenderal Soedirman Purwokerto).Tidak Diterbitkan.

Putri,D.P, (2008), Analisis Pengukuran Kinerja Perusahaan dengan Konsep Balanced Scorecard Studi Kasus Pada PT. Bank Tabungan Negara (Persero) Cabang Solo.Tidak Diterbitkan. 